\title{
Influence of synthetic superparamagnetic iron oxide on dendritic cells
}

This article was published in the following Dove Press journal:

International Journal of Nanomedicine

24 August 2011

Number of times this article has been viewed

\author{
Yongbin Mou' \\ Baoan Chen ${ }^{2}$ \\ Yu Zhang ${ }^{3}$ \\ Yayi Hou ${ }^{4}$ \\ $\mathrm{HaO} \mathrm{Xie}^{4}$ \\ Guohua Xia ${ }^{2}$ \\ Meng Tang ${ }^{5}$ \\ Xiaofeng Huang' \\ Yanhong $\mathrm{Ni}^{1}$ \\ Qingang $\mathrm{Hu}^{1,6}$
}

'Central Laboratory of Stomatology, Stomatological Hospital Affiliated Medical School, Nanjing University,

${ }^{2}$ Department of Hematology, Zhongda Hospital, Medical School, Southeast

University, ${ }^{3}$ State Key Laboratory of

Bioelectronics, Jiangsu Key Laboratory

for Biomaterials and Devices,

Southeast University, ${ }^{4}$ Immunology

and Reproductive Biology Laboratory,

Medical School, Nanjing University,

${ }^{5}$ Laboratory of Environmental

Medicine and Engineering, Ministry of

Education, School of Public Health,

Southeast University, Nanjing, People's

Republic of China; ${ }^{6}$ Leeds Dental

Institute, Faculty of Medicine and

Health, University of Leeds, Leeds, UK

Correspondence: Qingang Hu Central Laboratory of Stomatology, Stomatological Hospital Affiliated Medical School, Nanjing University, Nanjing 210008, People's Republic of China

Tel +86258362 0l0 I

Fax +86258362 0101

Email qghu@nju.edu.cn
Background: This study investigated the influence of synthetic superparamagnetic iron oxide (SPIO) on dendritic cells and provides a possible method for labeling these cells.

Methods: SPIO nanoparticles were prepared, and their morphology and magnetic properties were characterized. The particles were endocytosed by dendritic cells generated from mouse bone marrow. Labeling efficiency and cellular uptake were analyzed by Prussian blue staining and quantitative spectrophotometric assay. Meanwhile, the surface molecules, cellular apoptosis, and functional properties of the SPIO-labeled dendritic cells were explored by flow cytometry and the mixed lymphocyte reaction assay.

Results: The synthetic nanoparticles possessed a spherical shape and good superparamagnetic behavior. The mean concentration of iron in immature and mature dendritic cells was $31.8 \pm 0.7 \mu \mathrm{g}$ and $35.6 \pm 1.0 \mu \mathrm{g}$ per $1 \times 10^{6}$ cells, respectively. After 12 hours of incubation with SPIO at a concentration of $25 \mu \mathrm{g} / \mathrm{mL}$, nearly all cells were shown to contain iron. Interestingly, cellular apoptosis and surface expression of CD80, CD86, major histocompatibility II, and chemokine receptor 7 in mature dendritic cells were not affected to any significant extent by SPIO labeling. $\mathrm{T}$ cell activation was maintained at a low ratio of dendritic cells to $\mathrm{T}$ cells.

Conclusion: SPIO nanoparticles have good superparamagnetic behavior, highly biocompatible characteristics, and are suitable for use in further study of the migratory behavior and biodistribution of dendritic cells in vivo.

Keywords: superparamagnetic iron oxide, dendritic cell, cell labeling

\section{Introduction}

Due to their multifunctional properties, including a small size effect, superparamagnetism, and inherent biocompatibility, magnetic nanoparticles are being used increasingly for medical diagnosis and therapy, and especially for biomedical and biotechnology applications, including targeted drug delivery systems, contrast agents for magnetic resonance imaging, and hyperthermia for tumor therapy. ${ }^{1-3}$ In cell biology research, superparamagnetic iron oxide (SPIO) particles can be used for cell labeling, cell sorting, separation, and purification procedures.$^{4-7}$ Although they are very promising for in vivo application in imaging and drug delivery, there has been concern about their biological safety, so their use has been restricted.

Dendritic cells are major antigen-presenting cells in the initiation and development of adaptive immune responses against bacteria, viruses, allergens, and tumor antigens. Essentially, dendritic cells induce potent immune responses via their ability to migrate from the periphery via afferent lymphatics to areas containing $\mathrm{T}$ cells in secondary lymphoid organs. ${ }^{8}$ 
Immature dendritic cells residing in peripheral tissues monitor the microenvironment, and mature when starting to take up different antigens. During maturation, immature dendritic cells alter surface molecules, decreasing phagocytic ability, and strengthening their ability to migrate to lymph nodes, where they activate naive T cells via major histocompatibility complex (MHC) and costimulatory molecules. ${ }^{9-11}$

However, clinical studies of the ability of a dendritic cell vaccine to induce immunity against tumors did not demonstrate effective antitumor immunity. ${ }^{12,13}$ Because the responses of dendritic cell vaccine were not stable in clinical trials, monitoring of the injected cells may be important. Because of its ability to provide additional anatomical information and more detailed visualization, magnetic resonance imaging (MRI) may be an useful method for detecting labeled cells. The purpose of this study was to establish an efficient labeling method for dendritic cells in mouse bone marrow and to assess the influence of synthesized SPIO on dendritic cells for tracking them in vivo by MRI in the future.

\section{Materials and methods Materials}

Ferric chloride $\left(\mathrm{FeCl}_{3} \cdot 6 \mathrm{H}_{2} \mathrm{O}\right)$, ferrous sulfate $\left(\mathrm{FeSO}_{4} \cdot 7 \mathrm{H}_{2} \mathrm{O}\right)$, and hydrochloric acid (30\%) were purchased from Sinopharm Chemical Reagent Co Ltd, Shanghai, China. Tetramethylammonium hydroxide was from Shanghai Lingfeng Chemical Reagent Co Ltd, Shanghai, China. Other materials were RPMI 1640 medium, penicillin, and streptomycin (Gibco-Invitrogen, Grand Island, NY), fetal bovine serum (Gibco, Life Technologies, Breda, the Netherlands), recombinant murine granulocyte-macrophage colony-stimulating factor, recombinant murine interleukin-4, CD11c, B7-1 (CD80), B7-2(CD86), MHC II, and chemokine receptor 7 (eBioscience, San Diego, CA), tumor necrosis factor- $\alpha$, interleukin- $\beta$, and interleukin-6 (Peprotech, Rocky Hills, NJ), prostaglandin E2 (Sigma-Aldrich, St Louis, MO), a Prussian blue staining kit (Shanghai Yuanye BioTechnology Co Ltd, China). Annexin V and propidium iodide (Biouniquer, Biostar, China), and the Cell Counting Kit-8 (Dojindo, Japan).

\section{Preparation of SPIO}

$\gamma$ - $\mathrm{Fe}_{2} \mathrm{O}_{3}$ nanoparticles were prepared according to a method we have described previously. ${ }^{14}$ Briefly, $200 \mathrm{~mL}$ of aqueous tetramethylammonium hydroxide $1.5 \mathrm{M}$ solution was added to a $500 \mathrm{~mL}$ aqueous solution containing $\mathrm{FeCl}_{3} 0.1 \mathrm{M}$ and $\mathrm{FeSO}_{4} 0.05 \mathrm{M}$ with vigorous stirring at room temperature for
30 minutes. The resulting $\mathrm{Fe}_{3} \mathrm{O}_{4}$ nanoparticles were washed by magnetic separation and redispersed in water at $\mathrm{pH} 3.0$ and a concentration of $3 \mathrm{mg} / \mathrm{mL}$, then oxidized into brown $\gamma-\mathrm{Fe}_{2} \mathrm{O}_{3}$ nanoparticles by aeration at $95^{\circ} \mathrm{C}$. The $\gamma-\mathrm{Fe}_{2} \mathrm{O}_{3}$ nanoparticles obtained were dialyzed using an aqueous solution of hydrochloric acid at $\mathrm{pH} 3.0$, and the final concentration was adjusted to $25 \mathrm{mg} / \mathrm{mL}$ for the cell labeling experiments.

The particle size and morphology of the $\gamma-\mathrm{Fe}_{2} \mathrm{O}_{3}$ nanoparticles obtained was characterized by transmission electronic microscopy (JEOL JEM-2100). The magnetic properties were measured by a vibrating sample magnetometer (Lakeshore 7407). Photon correlation spectroscopy was used to determine the hydrodynamic size distribution using an N4 Plus submicron particle analyzer (Beckman Coulter, Indianapolis, IN), and surface charge measurements were performed using a Delsa 440SX zeta potential analyzer (Beckman Coulter).

\section{Mice}

Female BALB/c and C57BL/6 mice were purchased from the Animal Research Center of Yangzhou University, People's Republic of China, and kept under pathogen-free conditions in the central animal facility at Nanjing University. In a typical experiment, bone marrow was isolated from the femurs of 8-10-week-old mice weighing from 20-22 g. All animal experiments were performed in accordance with protocols approved by the animal care and use committee of the Medical School, Nanjing University, China.

\section{Cell culture}

Monocytes were isolated from mouse bone marrow. Marrow monocytes were flushed out from the femurs and tibias of the mice, cultured with RPMI 1640 medium supplemented with $10 \%$ fetal bovine serum, $100 \mathrm{U} / \mathrm{mL}$ penicillin, $100 \mathrm{mg} / \mathrm{mL}$ streptomycin, $10 \mathrm{ng} / \mathrm{mL}$ recombinant murine granulocytemacrophage colony-stimulating factor, and $1 \mathrm{ng} / \mathrm{mL}$ recombinant murine interleukin- $4 .{ }^{15}$ On days 2 and 4, 50\% of the medium was removed and fresh media was added. The released immature, nonadherent dendritic cells were collected on day 6 . The cells were stimulated with $10 \mathrm{ng} / \mathrm{mL}$ tumor necrosis factor- $\alpha, 10 \mathrm{ng} / \mathrm{mL}$ interleukin- $1 \beta, 10 \mathrm{ng} / \mathrm{mL}$ interleukin-6, and $1 \mu \mathrm{g} / \mathrm{mL}$ prostaglandin $\mathrm{E} 2$ for 48 hours. ${ }^{16,17}$ The mature dendritic cells were collected on day 8 .

\section{Cell labeling and Prussian blue staining}

Immature and mature dendritic cells were incubated with SPIO $25 \mu \mathrm{g} / \mathrm{mL}$ for 12 hours at $37^{\circ} \mathrm{C}$ in $5 \% \mathrm{CO}_{2}$. Cells were washed three times in phosphate-buffered solution 
and cytospins were prepared. Iron labeling efficiency was verified by Prussian blue staining. Labeled dendritic cells on cytospins were fixed with $4 \%$ paraformaldehyde for 30 minutes at room temperature, washed, and incubated with $2 \%$ potassium ferrocyanide in $2 \%$ hydrochloric acid for 30 minutes, and washed again. Screenings were performed at high magnification $(\times 400)$ using a light microscope (Olympus, CKX41-A32PH, Japan).

\section{Flow cytometry}

For phenotypic analysis, both labeled and unlabeled dendritic cells were harvested, washed thoroughly, individually stained with allophycocyanin-conjugated monoclonal antibodies specific for $\mathrm{CD} 11 \mathrm{c}$, fluorescein isothiocyanate-conjugated for MHC-II, phycoerythrin-conjugated for CD80, CD86, and chemokine receptor 7, according to the manufacturer's instructions, and studied by flow cytometry (Calibur, Becton Dickinson, San Antonio, TX). Meanwhile, apoptosis rates were measured. Briefly, cells labeled or unlabeled with SPIO were collected, and stained with Annexin V and propidium iodide. After being washed, the apoptotic cells were studied by flow cytometry and analyzed using Cell Quest software.

\section{Cellular uptake of SPIO}

The SPIO uptake by dendritic cells was assessed according to the method described by Ge et al. ${ }^{18}$ Briefly, immature and mature dendritic cells were collected, washed with phosphate-buffered saline, and resuspended in $30 \% \mathrm{HCl}$ $(\mathrm{v} / \mathrm{v})$ at $60^{\circ} \mathrm{C}$ for two hours. Potassic persulfate $1.0 \mathrm{mg}$ was then added to oxidize the ferrous ions in the above solution to ferric ions. Potassium thiocyanate $0.1 \mathrm{M} 1.0 \mathrm{~mL}$ was added to form the iron-thiocyanate complex. A $150 \mu \mathrm{L}$ quantity of the mixture was transferred to a flat-bottomed 96-well plate (Corning Costar, Cambridge, MA). The absorbance was measured at $480 \mathrm{~nm}$ using a microplate reader 10 minutes later (Bio-Tek Instruments Inc, Winooski, CT). A standard curve of an aqueous $\mathrm{FeCl}_{3} \cdot 6 \mathrm{H}_{2} \mathrm{O}$ solution was treated in the same manner to quantify the amount of SPIO uptake in the cells. The iron content of the SPIO-labeled dendritic cells was expressed as the amount of $\mathrm{Fe}_{2} \mathrm{O}_{3}$.

\section{Mixed lymphocyte reaction assay}

Dendritic cells labeled with SPIO were collected and washed. Purified $\mathrm{CD}^{+} \mathrm{T}$ cells were obtained by positive magnetic bead separation (Miltenyi Biotec, Boston, MA) from the lymph nodes (axillary, inguinal, mesenteric) of normal $\mathrm{BALB} / \mathrm{c}$ mice. Allogeneic $\mathrm{T}$ cells were incubated with dendritic cells or SPIO-labeled dendritic cells at ratios of 5:1,
10:1, 50:1, and 100:1 in flat-bottomed 96-well plates. After incubation for three days, cell activation and proliferation was evaluated using a Cell Counting Kit-8, and the absorbances were read at $450 \mathrm{~nm}$ using the microplate reader according to the manufacturer's instructions.

\section{Statistical analysis}

Data were analyzed using the Statistical Package for Social Science (version 13.0, SPSS Inc, Chicago, IL). Results were expressed as means \pm standard deviation, and differences between control and test groups were assessed by one-way analysis of variance and two-tailed Student's $t$-test. The level of statistical significance was set at $P<0.05$.

\section{Results \\ Characterization of SPIO}

Under transmission electron microscopy, $\gamma-\mathrm{Fe}_{2} \mathrm{O}_{3}$ nanoparticles were measured at an average diameter around $8.7 \mathrm{~nm}$, and were seen as nearly spherical shapes (Figure 1A). A vibrating sample magnetometer demonstrated that the $\gamma$ - $\mathrm{Fe}_{2} \mathrm{O}_{3}$ nanoparticles obtained possessed superparamagnetic behavior, with saturation magnetization of $60.4 \mathrm{emu} / \mathrm{g}$ (Figure 1B). The average hydrodynamic size of the $\gamma-\mathrm{Fe}_{2} \mathrm{O}_{3}$ nanoparticles in water was $92 \mathrm{~nm}$, and the zeta potential had a positive surface charge of $20.9 \mathrm{mV}$.

\section{SPIO labeling efficiency and cell phenotypes}

Prussian blue staining was performed to evaluate SPIO labeling efficiency. After 12 hours of incubation with SPIO at a concentration of $25 \mu \mathrm{g} / \mathrm{mL}$, nearly all cells were shown to contain iron (Figure 2). Before study of the phenotypic changes in labeled dendritic cells, the ratio of dendritic cells in the induced marrow monocytes was analyzed. The results indicated that $80 \%$ of the cells were CD11 $\mathrm{c}^{+}$, which is regarded as a major marker for dendritic cells (Figure 3).

To determine whether dendritic cell surfaces would be influenced by SPIO labeling, an immunostaining assay was performed with a panel of antibodies against the costimulatory molecules CD80, CD86, MHC-II, and chemokine receptor 7 , followed by flow cytometry analysis. After being stimulated by tumor necrosis factor- $\alpha$, interleukin- $1 \beta$, interleukin-6, and prostaglandin E2, expression of CD80, CD86, MHC-II, and chemokine receptor 7 was significantly increased in mature dendritic cells compared with immature dendritic cells. Expression of these four markers in mature dendritic cells and mature SPIO-labeled dendritic cells was similar, with no statistically significant difference between the 

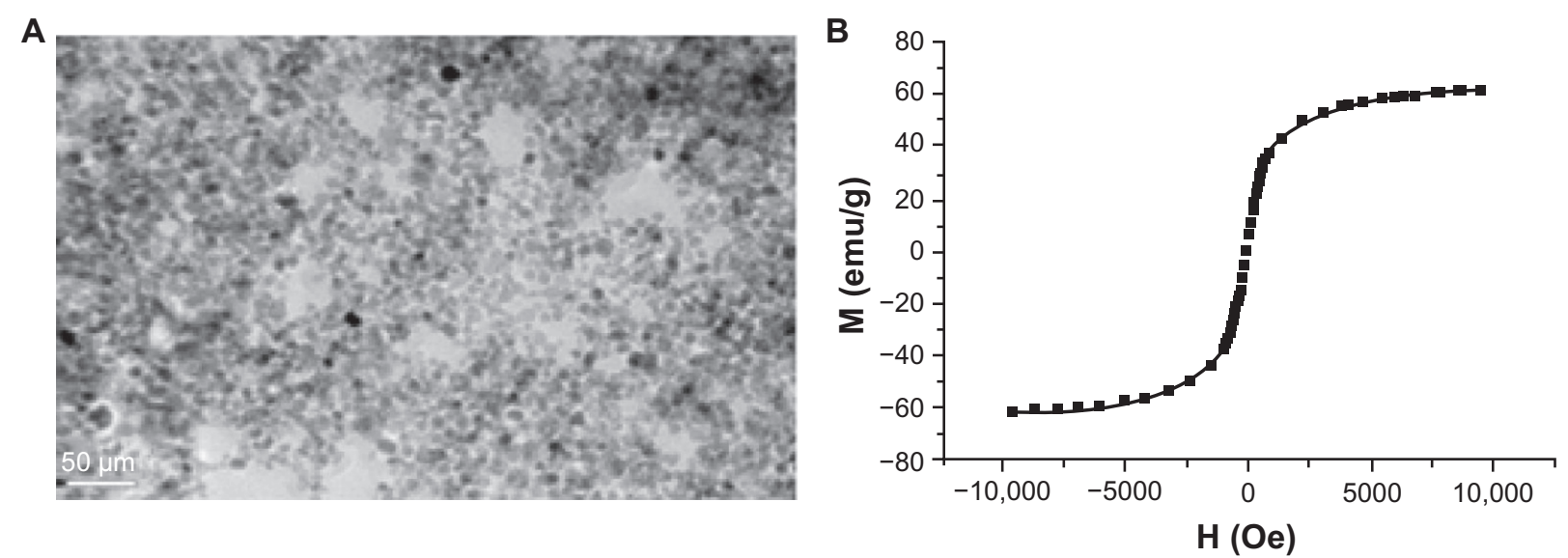

Figure I Characteristics of $\gamma$ - $\mathrm{Fe}_{2} \mathrm{O}_{3}$ nanoparticles. (A) Transmission electron microscopic image of the obtained $\gamma$-Fe $\mathrm{O}_{3}$ nanoparticles and (B) hysteresis loop of the obtained $\gamma-\mathrm{Fe}_{2} \mathrm{O}_{3}$ nanoparticles at room temperature.

groups $(P>0.05)$. In contrast, compared with unlabeled cells, expression of CD80, CD86, and MHC-II on SPIO-labeled immature dendritic cells was upregulated, while chemokine receptor 7 remained at almost the same level (Figure 4).

\section{Cell apoptosis}

To test whether dendritic cells labeled with SPIO nanoparticles could have any influence on cell apoptosis, both mature dendritic cells and mature SPIO-labeled dendritic cells were analyzed by flow cytometry using Annexin V-propidium iodide methods at different time points $(0,6$, 12, 24, and 36 hours). The results indicate no significant difference in cell apoptosis between mature dendritic cells and mature SPIO-labeled dendritic cells (Figure 5).

\section{Cellular uptake of SPIO}

SPIO particles internalized by dendritic cells were examined using a quantitative spectrophotometric method. There was a linear correlation $\left(\mathrm{r}^{2}>0.99\right)$ between absorbance and concentration of nanoparticles in culture medium. On average, the mean concentration of iron in immature SPIO-labeled dendritic cells and mature SPIO dendritic cells was $31.8 \pm 0.7 \mu \mathrm{g}$ and $35.6 \pm 1.0 \mu \mathrm{g}$ per $1 \times 10^{6}$ cells, respectively (Figure 6).
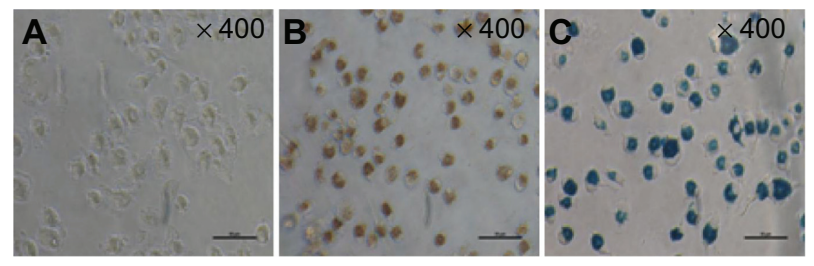

Figure 2 Morphology of dendritic cells labeled with $25 \mu \mathrm{g} / \mathrm{mL}$ superparamagnetic iron oxide particles after 12 hours incubation (Prussian blue staining, $\times 400$ ). (A) unlabeled dendritic cells, (B) dendritic cells labeled with superparamagnetic iron oxide, and (C) labeled dendritic cells with Prussian blue staining. Note: Scale: $50 \mu \mathrm{m}$.

\section{Mixed lymphocyte reaction assay}

The mixed lymphocyte reaction assay used to observe the functional properties of SPIO-labeled dendritic cells used ratios of dendritic cells to $T$ cells of 1:5, 1:10, 1:50, and 1:100, respectively. Activation and proliferation of $\mathrm{T}$ cells was notably decreased as the ratios decreased from 1:5 to 1:100. Both mature SPIO-labeled and unlabeled dendritic cells showed a significant increase in $\mathrm{T}$ cell activation and proliferation when the ratio of dendritic cells to $\mathrm{T}$ cells was 1:5. Similar results were observed for immature dendritic cells and immature SPIO-labeled dendritic cells, but the absorbance of mature SPIO-labeled dendritic cells was lower than that of mature dendritic cells $(P<0.05)$. There was no significant difference detected at other ratios (Figure 7).

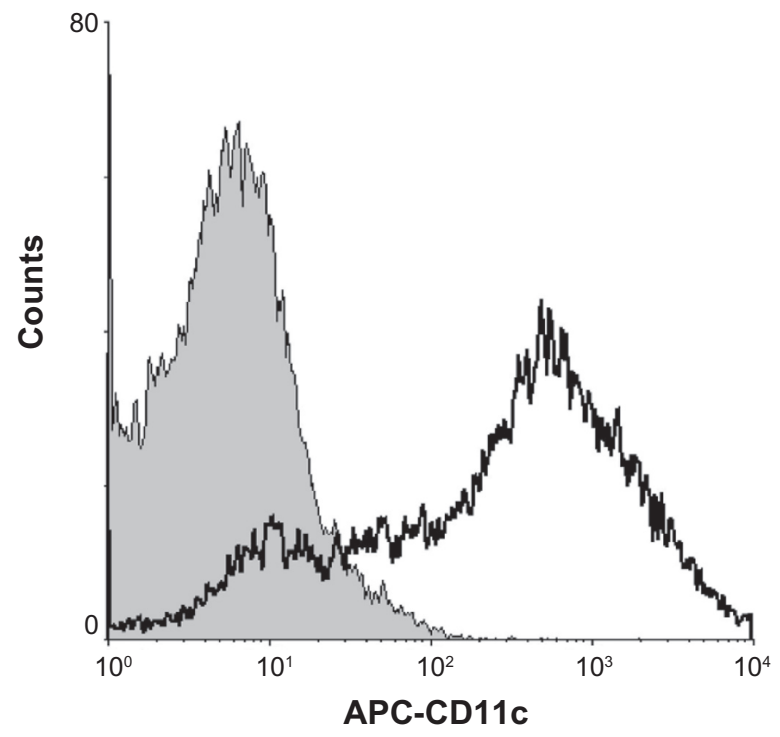

Figure $3 \mathrm{CDII} \mathrm{I}^{+}$cells were examined by flow cytometry after being stained with allophycocyanin-conjugated monoclonal antibodies.

Abbreviation: APC, allophycocyanin. 
CD80

iDC
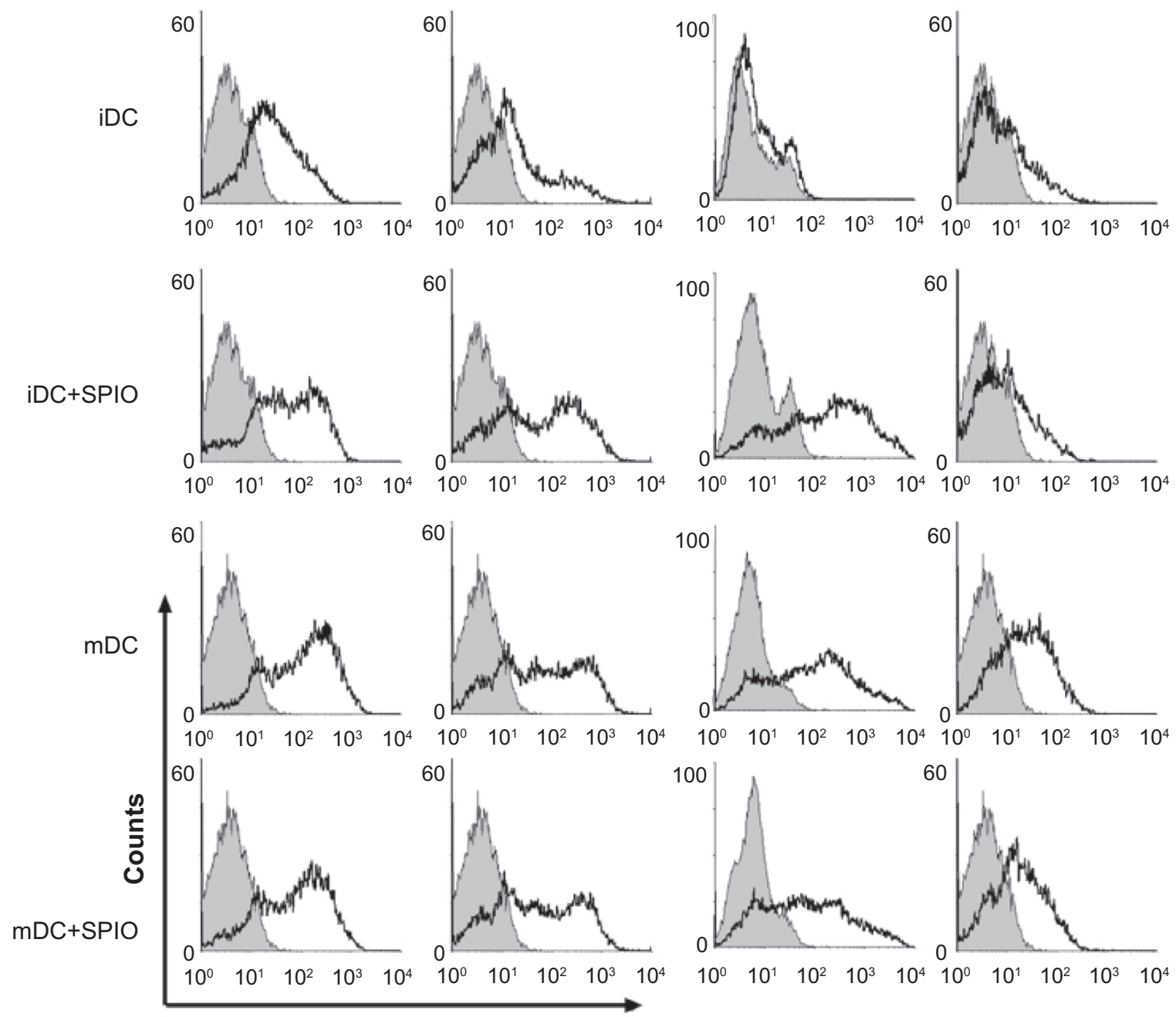

\section{Fluorescence}

Figure 4 Phenotypic changes of dendritic cells after labeling with superparamagnetic iron oxide particles.

Abbreviations: iDCs, immature dendritic cells; mDCs, mature dendritic cells; SPIO, superparamagnetic iron oxide.

A

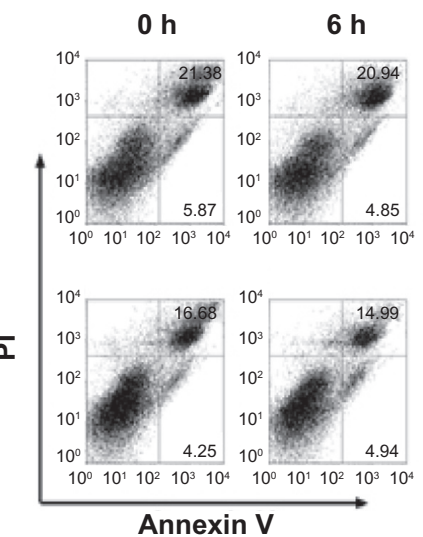

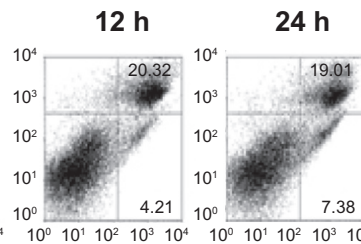

$24 \mathrm{~h}$
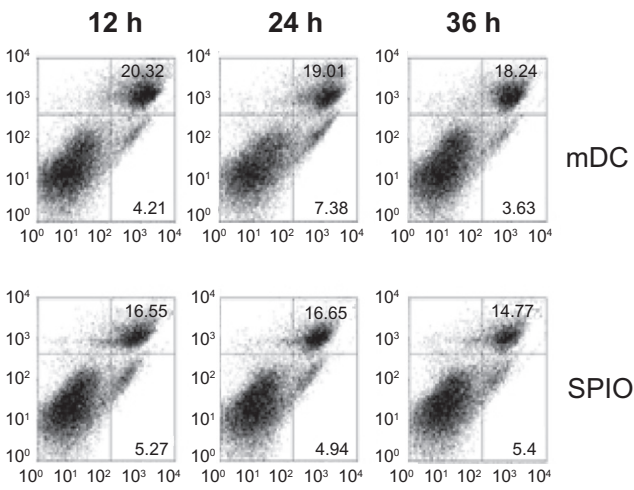

B

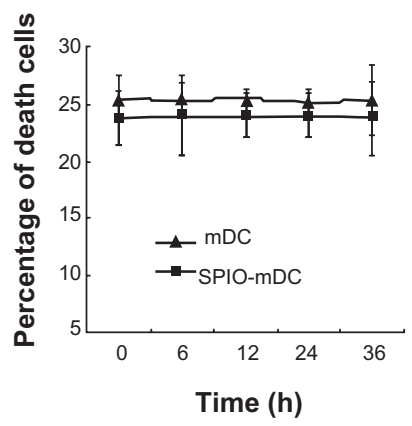

Figure 5 Cell apoptosis of mature dendritic cells and superparamagnetic iron oxide-mature dendritic cells was determined by flow cytometry at different time points ( 0,6 , 12, 24, and 36 hours). (A) Cell apoptosis by flow cytometry and (B) cell death curve.

Abbreviations: $h$, hour; $\mathrm{mDC}$, mature dendritic cells; SPIO, superparamagnetic iron oxide. 
A

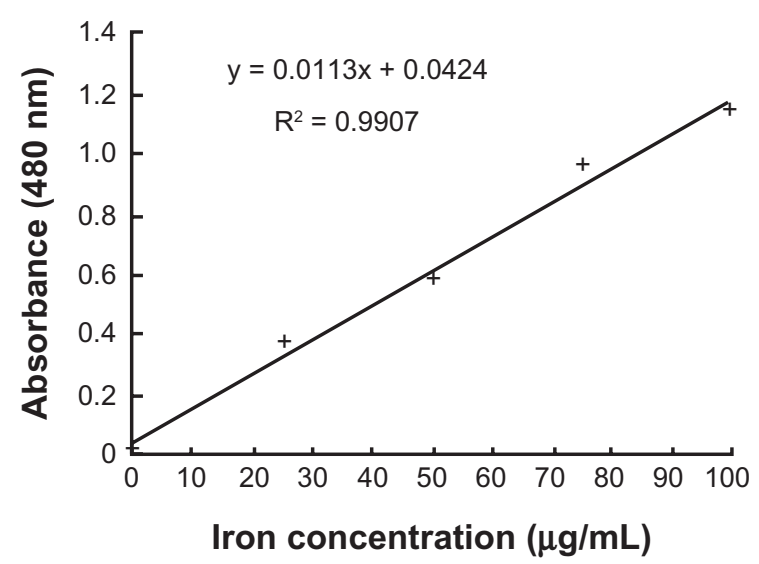

B

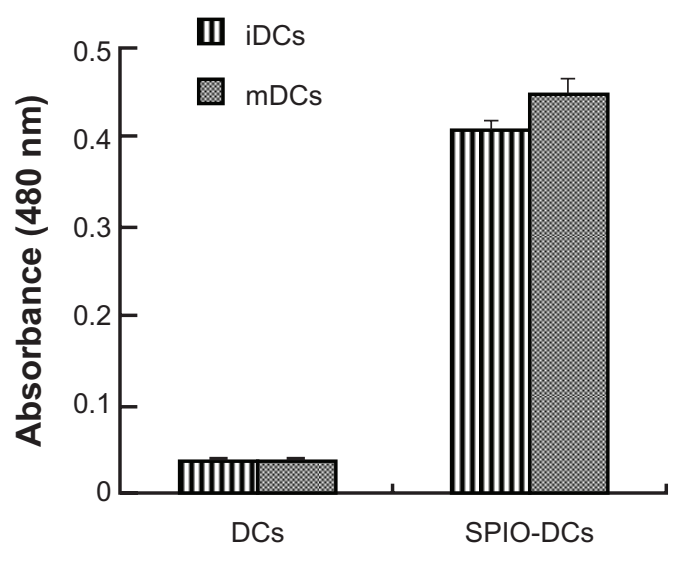

Figure 6 Standard curve of iron and cellular uptake of superparamagnetic iron oxide by dendritic cells at 12 hours of coculture time. (A) Standard curve of an aqueous $\mathrm{FeCl}_{3} \cdot 6 \mathrm{H}_{2} \mathrm{O}$ solution with different concentrations of $\mathrm{FeCl}_{3} \cdot 6 \mathrm{H}_{2} \mathrm{O}\left(\mathrm{r}^{2}>0.99\right)$. (B) Mean concentrations of iron in immature dendritic cells and mature dendritic cells after coculturing with superparamagnetic iron oxide $25 \mu \mathrm{g} / \mathrm{mL}$ for 12 hours.

Abbreviations: iDCs, immature dendritic cells; mDCs, mature dendritic cells; SPIO, superparamagnetic iron oxide.

\section{Discussion}

The basic criteria for the use of SPIO in bioscience are safety and biocompatibility, which are determined by size and superficial characteristics. Superparamagnetic $\mathrm{Fe}_{3} \mathrm{O}_{4}$ nanoparticles have demonstrated good biocompatibility and safety when used as drug carriers and targeted tumor therapy. ${ }^{19,20}$ $\gamma-\mathrm{Fe}_{2} \mathrm{O}_{3}$ nanoparticles with a positive surface charge were synthesized by oxidation and acidification from $\mathrm{Fe}_{3} \mathrm{O}_{4}$ and had a good superparamagnetic behavior. The precursors were prepared according to a modified Massart method and

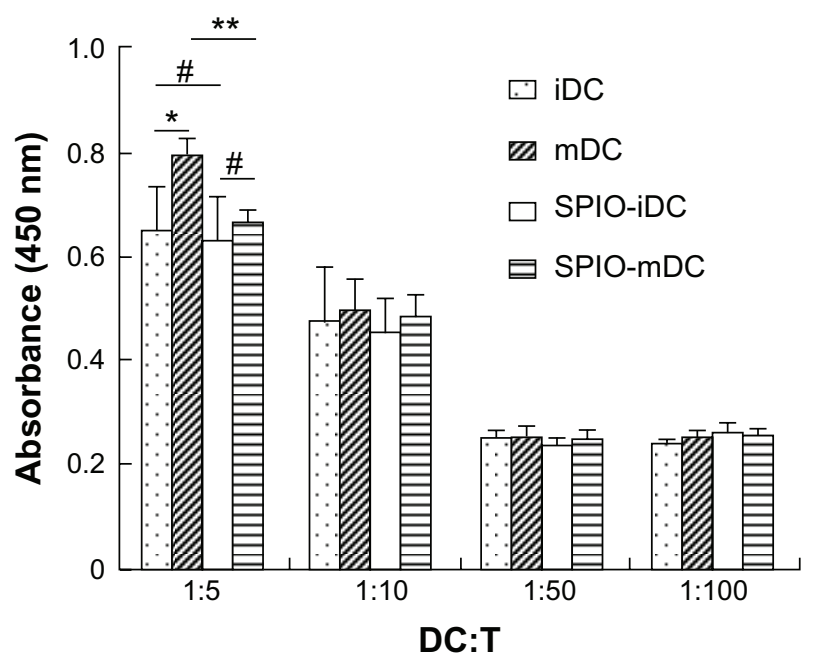

Figure 7 Mixed lymphocyte reaction of dendritic cells and superparamagnetic iron oxide impregnated dendritic cells with allogeneic T cells. Dendritic cells derived from bone marrow and labeled with SPIO $(25 \mu \mathrm{g} / \mathrm{mL}, 12$ hours of incubation) were cocultured with allogenic $T$ cells for 3 days at ratios of 1:5, 1:10, 1:50, 1:100, and proliferation of T cells was measured by the Cell Counting Kit-8 method $(450 \mathrm{~nm})$. Notes: ${ }^{*} P<0.05,{ }^{* * P}<0.05$, statistically significant; ${ }^{*} P>0.05$, not statistically significant.

Abbreviations: iDC, immature dendritic cells; mDCs, mature dendritic cells; SPIO, superparamagnetic iron oxide; DC, dendritic cells; T, T cells. reduction coprecipitation without argon protection. ${ }^{21,22}$ SPIO preparation was simple and feasible, and the characteristics of synthetic SPIO were proved to be suitable for biological application (Figure 1).

Because the immune response of dendritic cell vaccines against solid tumors has often been shown to be weak or localized, there has been concern about the need to track migration of dendritic cells accurately in vivo. In this study, a novel approach to forming SPIO-labeled dendritic cells was introduced, and the influence of SPIO on dendritic cells was investigated. SPIO is an attractive contrast agent for cell migration. It is a biodegradable and feasible agent for study of living cells by MRI in vitro and in vivo. ${ }^{14,23}$ Due to the phagocytic properties and negative membrane potential of dendritic cells, SPIO-labeled nanoparticles could be easily delivered to the cells. ${ }^{24}$ In our study, SPIO was internalized into dendritic cells, and this was confirmed by Prussian blue staining (Figure 2).

Before evaluating the influence of SPIO-labeled dendritic cells, the dendritic cells were first identified. CD11c is widely regarded as a major marker for dendritic cells. In this study, flow cytometry indicated that $80 \%$ of bone marrow monocytes were $\mathrm{CD} 11 \mathrm{c}^{+}$, showing this to be a reliable method for providing sufficient cells for further studies (Figure 3).

Phenotype and maturation of dendritic cells are critical factors which may be changed by SPIO labeling. In our study, after immature dendritic cells were labeled by SPIO, expression of CD80, CD86, and MHC II was found to be upregulated, while chemokine receptor 7 levels remained unchanged. We hypothesize that SPIO was engulfed as antigens by immature dendritic cells, which induced early 
maturation of these dendritic cells. Although MHC II was upregulated, there were no actual antigen formation via MHC II which could explain the unaltered expression of chemokine receptor 7. After stimulation by inflammatory cytokines, ie, tumor necrosis factor- $\alpha$, interleukin- $1 \beta$, interleukin-6, and prostaglandin E2, the expression of these four markers was increased significantly in both labeled and unlabeled mature dendritic cells. These findings suggested that SPIO had little influence on the phenotypes of mature dendritic cells (Figure 4). Moreover, there was no significant change in apoptosis after SPIO labeling (Figure 5).

Furthermore, the concentration of intracellular iron in SPIO-labeled dendritic cells was measured. The optimal concentration and coculture time of SPIO for dendritic cell-labeling were $25 \mu \mathrm{g} / \mathrm{mL}$ and 12 hours, respectively, as shown in our previous study (data not shown). Cells containing iron were found to carry an average amount of $31.8 \pm 0.7 \mu \mathrm{g}$ per $1 \times 10^{6}$ cells in immature dendritic cells and $35.6 \pm 1.0 \mu \mathrm{g}$ per $1 \times 10^{6}$ cells in mature dendritic cells (Figure 6). Verdijk et $\mathrm{al}^{25}$ have shown that an average of $30 \mu \mathrm{g}$ iron per $1 \times 10^{6}$ cells will not hinder cell viability, with the concentration of SPIO in their study set as $200 \mu \mathrm{g}$ ferrum oxide $/ \mathrm{mL}$ and a coculture time of 4 days. In contrast, this type of synthetic SPIO was shown to be more easily inserted, independent of concentration or coculture time, than suggested by previous reports..$^{25,26}$

To confirm whether SPIO labeling could affect function and apoptosis of dendritic cells, the capacities of antigenprocessing, presenting, and naive allogeneic $\mathrm{T}$ cells stimulated by dendritic cells were tested by a mixed leukocyte reaction assay. The results showed that dendritic cells could maintain $T$ cell activation and proliferation after being labeled by SPIO, except if the ratio of dendritic cells to $\mathrm{T}$ cells was $1: 5$, when the stimulating ability of mature dendritic cells was partly limited by SPIO. A similar phenomenon was not found for the other experimental groups (Figure 7). Because the proportion of dendritic cells in the peripheral tissues was very low, the number of dendritic cells migrating from the periphery to the secondary lymphoid organs was estimated to be less than $10 \%,{ }^{8,28}$ and the possibility of the ratio being restricted to 1:5 was almost impossible. Similar results have been obtained using other types of SPIO. ${ }^{29}$

\section{Conclusion}

From the data presented, SPIO has a negligible influence on dendritic cell function, especially mature dendritic cells. This study describes a novel approach for MRI investigation of dendritic cell migration. Hopefully, our work will serve as a useful method for evaluating activation of the immune response against tumor tissue by dendritic cell vaccines in the future.

\section{Acknowledgments}

The authors are grateful for grants from the National Natural Sciences Foundation of China (No. 30870679, 81072213), National Important Science Research Program of China (No. 2011CB933503, 2011CB933404), Research Projected by Jiangsu Department of Health (No. H200944), and the Nanjing Medical Development Foundation (No. ZKX10031).

\section{Disclosure}

The authors report no conflicts of interest in this work.

\section{References}

1. Singh R, Lillard JW Jr. Nanoparticle-based targeted drug delivery. Exp Mol Pathol. 2009;86:215-223.

2. Peng XH, Qian X, Mao H, et al. Targeted magnetic iron oxide nanoparticles for tumor imaging and therapy. Int J Nanomedicine. 2008;3: 311-321.

3. Comes Franchini M, Baldi G, Bonacchi D, et al. Bovine serum albumin-based magnetic nanocarrier for MRI diagnosis and hyperthermia therapy: a potential theranostic approach against cancer. Small. 2010;6: 366-370.

4. Long CM, van Laarhoven HWM, Bulte JWM, Levitsky HI. Magnetovaccination as a novel method to assess and quantify dendritic cell tumor antigen capture and delivery to lymph nodes. Cancer Res. 2009;69: 3180-3187.

5. Ström V, Hultenby K, Grüttner C, Teller J, Xu B, Holgersson J. A novel and rapid method for quantification of magnetic nanoparticlecell interactions using a desktop susceptometer. Nanotechnology. 2004; 15:457-466.

6. Shen YF, Tang J, Nie ZH, Wang YD, Ren Y, Zuo L. Preparation and application of magnetic $\mathrm{Fe}_{3} \mathrm{O}_{4}$ nanoparticles for wastewater purification. Sep Purif Technol. 2009;68:312-319.

7. Naqvi S, Samim M, Abdin MZ, et al. Concentration-dependent toxicity of iron oxide nanoparticles mediated by increased oxidative stress. Int J Nanomedicine. 2010;5:983-989.

8. Martin-Fontecha A, Sebastiani S, Höpken UE, et al. Regulation of dendritic cell migration to the draining lymph node: impact on T lymphocyte traffic and priming. J Exp Med. 2003;198:615-621.

9. Mittelbrunn M, del Hoyo GM, Lopez-Bravo M, et al. Imaging of plasmacytoid dendritic cell interactions with T cells. Blood. 2009;113: 75-84.

10. Fujisawa Y, Nabekura T, Nakao T, et al. The induction of tumor-specific $\mathrm{CD}^{+} \mathrm{T}$ cells via major histocompatibility complex class II is required to gain optimal anti-tumor immunity against B16 melanoma cell line in tumor immunotherapy using dendritic cells. Exp Dermatol. 2009; 18:396-403.

11. Agrawal S, Gupta S, Agrawal A. Vaccinia virus proteins activate human dendritic cells to induce T cell responses in vitro. Vaccine. 2009;27: 88-92.

12. Norian LA, Rodriguez PC, O’Mara LA, et al. Tumor-infiltrating regulatory dendritic cells inhibit CD8(+) $\mathrm{T}$ cell function via $\mathrm{L}$-arginine metabolism. Cancer Res. 2009;69:3086-3094.

13. Liu Q, Zhang C, Sun A, Zheng Y, Wang L, Cao X. Tumor-educated CD11b highIalow regulatory dendritic cells suppress $\mathrm{T}$ cell response through arginase I. J Immunol. 2009;182:6207-6216.

14. Sun YK, Ma M, Zhang Y, Gu N. Synthesis of nanometer-size maghemite particles from magnetite. Colloids Surf A Physicochem Eng Asp. 2004; 245:15-19. 
15. Xie H, Hua C, Sun L, et al. 17ß-Estradiol induce CD40 expression in dendritic cells via MAPK signaling pathways in a MCM6 dependent way. Arthritis Rheum. May 2, 2011. [Epub ahead of print.]

16. Mu LJ, Gaudernack G, Saebøe-Larssen S, Hammerstad H, Tierens A, Kvalheim G. A protocol for generation of clinical grade mRNA transfected monocyte-derived dendritic cells for cancer vaccines. Scand $J$ Immunol. 2003;58:578-586.

17. Scandella E, Men Y, Gillessen S, Förster R, Groettrup M. Prostaglandin E2 is a key factor for CCR7 surface expression and migration of monocyte-derived dendritic cells. Blood. 2002;100:1354-1361.

18. Ge YQ, Zhang Y, Xia JG, et al. Effect of surface charge and agglomerate degree of magnetic iron oxide nanoparticles on KB cellular uptake in vitro. Colloids Surf B Biointerfaces. 2009;73:294-301.

19. Wu W, Chen B, Cheng J, et al. Biocompatibility of $\mathrm{Fe}_{3} \mathrm{O}_{4} / \mathrm{DNR}$ magnetic nanoparticles in the treatment of hematologic malignancies. Int J Nanomedicine. 2010;5:1079-1084.

20. Wang J, Chen Y, Chen B, et al. Pharmacokinetic parameters and tissue distribution of magnetic $\mathrm{Fe}_{3} \mathrm{O}_{4}$ nanoparticles in mice. Int $J$ Nanomedicine. 2010;21:861-866.

21. Massart R. Preparation of aqueous magnetic liquids in alkaline and acidic media. IEEE Trans Magn. 1981;17:1247-1248.

22. Kang YS, Risbud S, Rabolt JF, Stroeve P. Synthesis and characterization of nanometer-size $\mathrm{Fe}_{3} \mathrm{O}_{4}$ and gamma- $\mathrm{Fe}_{2} \mathrm{O}_{3}$ particles. Chem Mater. 1996;8:2209-2212.
23. Zhang S, Chen XJ, Gu CR, et al. The effect of iron oxide magnetic nanoparticles on smooth muscle cells. Nanoscale Res Lett. 2009;4: 70-77.

24. Waeckerle-Men Y, Groettrup M. PLGA microspheres for improved antigen delivery to dendritic cells as cellular vaccines. Adv Drug Deliv Rev. 2005;57:475-482.

25. Verdijk P, Scheenen TW, Lesterhuis WJ, et al. Sensitivity of magnetic resonance imaging of dendritic cells for in vivo tracking of cellular cancer vaccines. Int J Cancer. 2006;120:978-984.

26. Lim YT, Noh YW, Han JH, Cai QY, Yoon KH, Chung BH. Biocompatible polymer-nanoparticle-based bimodal imaging contrast agents for the labeling and tracking of dendritic cells. Small. 2008;10: 1640-1645.

27. Schwarz S, Fernandes F, Sanroman L, et al. Synthetic and biogenic magnetite nanoparticles for tracking of stem cells and dendritic cells. J Magn Magn Mater. 2009;321:1533-1538.

28. Eggert AA, van der Voort R, Torensma R, et al. Analysis of dendritic cell trafficking using EGFP-transgenic mice. Immunol Lett. 2003;89: 17-24.

29. Dekaban GA, Snir J, Shrum B, et al. Semiquantitation of mouse dendritic cell migration in vivo using cellular MRI. J Immunother. 2009;32: $240-251$.
International Journal of Nanomedicine

\section{Publish your work in this journal}

The International Journal of Nanomedicine is an international, peerreviewed journal focusing on the application of nanotechnology in diagnostics, therapeutics, and drug delivery systems throughout the biomedical field. This journal is indexed on PubMed Central, MedLine, CAS, SciSearch $\AA$, Current Contents ${ } /$ Clinical Medicine,

\section{Dovepress}

Journal Citation Reports/Science Edition, EMBase, Scopus and the Elsevier Bibliographic databases. The manuscript management system is completely online and includes a very quick and fair peer-review system, which is all easy to use. Visit http://www.dovepress.com/ testimonials.php to read real quotes from published authors. 